\title{
Efficiency Analysis of Warm Gas Clean up in Integrated Gasification Fuel Cell (IGFC) System
}

\section{Peixuan Hao}

Tsinghua University

\author{
Xuancan Zhu \\ Shanghai Jiao Tong University \\ Shuang Li \\ Tsinghua University \\ Yixiang Shi ( $\nabla$ shyx@tsinghua.edu.cn ) \\ https://orcid.org/0000-0001-8720-9699 \\ Ningsheng Cai \\ Tsinghua University
}

\section{Research}

Keywords: IGFC, warm gas clean up, pressure swing adsorption, energy efficiency

Posted Date: July 20th, 2020

DOI: https://doi.org/10.21203/rs.3.rs-42837/v1

License: (c) (1) This work is licensed under a Creative Commons Attribution 4.0 International License. Read Full License 


\title{
Efficiency Analysis of Warm Gas Clean up in Integrated Gasification Fuel Cell (IGFC) System
}

\author{
Peixuan $\mathrm{Hao}^{1,3}$, Xuancan $\mathrm{Zhu}^{2}$, Shuang $\mathrm{Li}^{1,3}$, Yixiang Shi ${ }^{1,3}{ }^{*}$, Ningsheng Cai ${ }^{1,3}$ \\ 1. Key Laboratory for Thermal Science and Power Engineering of Ministry of \\ Education, Department of Energy and Power Engineering, Tsinghua University, \\ Beijing 100084, China \\ 2. Key Laboratory of Power Mechanical Engineering, Institute of Refrigeration and \\ Cryogenics, MOE China, Shanghai Jiao Tong University, 800 Dongchuan Road, \\ Shanghai 200240, China \\ 3. Shanxi Research Institute for Clean Energy, Tsinghua University, Taiyuan, Shanxi \\ Province, 030032, China \\ * Corresponding author, Republic of China. E-mail: shyx@tsinghua.edu.cn
}




\section{Abstract}

This study investigates the energy consumption of two kinds of pre-combustion $\mathrm{CO}_{2}$ capture technologies, the conventional Selexol process and the elevated temperature pressure swing adsorption (ET-PSA) process, in an integrated gasification fuel cell (IGFC) power plant. Power plant models with and without $\mathrm{CO}_{2}$ capture are built in Aspen Plus and the simulation of ET-PSA process is realized in gPROMS. Specific primary energy consumption for $\mathrm{CO}_{2}$ avoided (SPECCA), a function related to $\mathrm{CO}_{2}$ emission rate and electric efficiency, is used to quantitatively evaluate the $\mathrm{CO}_{2}$ capture energy consumption. ET-PSA technology purifies the syngas at over $150{ }^{\circ} \mathrm{C}$, avoiding the efficiency penalty caused by cooling and reheating processes in conventional purification methods. Adding reflux and rinse to ET-PSA procedures is proved to be effective ways to improve $\mathrm{H}_{2}$ recovery. When the $\mathrm{CO}_{2}$ capture rate is $90 \%$ and $99 \%$, the SPECCA of ET-PSA is 1.80 and $2.72 \mathrm{~kJ} / \mathrm{kg}$, respectively, while the corresponding outcomes of Selexol is 3.46 and $3.66 \mathrm{~kJ} / \mathrm{kg}$, respectively. The reduction of energy consumption is mainly attributed to the saving of sensible heat in the syngas.

\section{Keywords}

IGFC; warm gas clean up; pressure swing adsorption; energy efficiency

\section{Introduction}

Fossil fuel combustion is one of the major resources of greenhouse gas emissions. In order to release greenhouse effect, various $\mathrm{CO}_{2}$ capture technologies have been developed, including pre-combustion capture, post-combustion capture, 
oxy-combustion and chemical-looping combustion. Integrated gasification fuel cell (IGFC) electric power generation system is a kind of power generating plant which is suitable for pre-combustion $\mathrm{CO}_{2}$ capture. Adopting solid oxide fuel cell (SOFC) as the generation unit, the energy efficiency is higher than the integrated gasification combined cycle (IGCC) power plant. The IGFC is regarded as the development direction of power generating system.

The report of US Department of Energy (DOE) [Newby et al. 2011] presents the results of a Pathway Study for coal-based, IGFC power systems with carbon capture and sequestration. The performance of IGFC with atmospheric-pressure SOFC, pressurized SOFC, conventional gasification technology and catalytic gasification technology, including mass balances, energy flow, emission, and operating cost, were comprehensively analyzed. They also concluded that the use of natural gas injection into the coal-syngas stream may achieve IGFC plant performance improvement and cost enhancements. Subsequently, various IGFC cogeneration plant models were developed to analyze the exergy efficiency and optimize the system configuration [Ameri et al. 2013; Mehrpooya et al 2014; Lanzini et al. 2014; Sarmah et al. 2017; Hajabdollahi et al. 2017].

$\mathrm{CO}_{2}$ capture and syngas purification subsystem is a critical part in IGFC. The greenhouse gas and harmful gas are removed from the syngas in this unit. Currently, the most common syngas purification approaches in coal chemical industry are wet $\mathrm{CO}_{2}$ capture technology (e.g. Rectisol, Selexol, MDEA), where both high purity and recovery rate of product gas can be achieved. However, the operating temperatures of 
Selexol, Rectisol and MDEA range from -50 to $60{ }^{\circ} \mathrm{C}$ [Mohammed et al. 2014; Zhang et al. 2017]. Note that the syngas temperature is usually over $200{ }^{\circ} \mathrm{C}$, and thus the syngas needs pre-cooling and reheating after purification. The sensible heat loss would significantly influence the energy efficiency of IGFC system. In contrast, elevated temperature pressure swing adsorption (ET-PSA) works at elevated temperatures $\left(150-450{ }^{\circ} \mathrm{C}\right)$. The introduction of steam rinse in ET-PSA significantly improves the syngas recovery rate. Previous studies indicate that the ET-PSA technology might be more energy saving than the wet solvent $\mathrm{CO}_{2}$ capture technologies [Reynolds et al. 2006; Zhu et al. 2018].

Numerous studies were conducted on adsorbent development, process design and energy consumption analysis of ET-PSA. Li et al. [Li et al. 2013] developed a kind of Stearate-pillared layered double hydroxide (LDH) promoted by $\mathrm{K}_{2} \mathrm{CO}_{3}$. The $\mathrm{CO}_{2}$ adsorption capacity can reach $1.93 \mathrm{mmol} / \mathrm{g}$ at $300{ }^{\circ} \mathrm{C}, 1 \mathrm{~atm}$. Using the advanced preparation method, the adsorbent shows fast adsorption rate, high strength and excellent working performance stability. Coenen et al. [Coenen et al. 2017] characterized the hydrotalcites on thermogravimetric analysis (TGA) and packed bed, and suggested that at least four different adsorption sites participate in the adsorption/desorption of $\mathrm{CO}_{2}$ and $\mathrm{H}_{2} \mathrm{O}$. Regeneration with steam is advantageous to the $\mathrm{CO}_{2}$ cyclic working capacity. Qiao et al. [Qiao et al. 2017] developed a molten salt-promoted $\mathrm{MgO}$ for elevated temperature $\mathrm{CO}_{2}$ capture. They optimized ratio of $\mathrm{Li} / \mathrm{Na} / \mathrm{K}$ nitrates and the loading of the molten salt mixture on the $\mathrm{MgO}$ particles. Between 300 to $350{ }^{\circ} \mathrm{C}$, the $\mathrm{CO}_{2}$ adsorption capacity could even reach $16.8 \mathrm{mmol} / \mathrm{g}$. 
In the project of TDA Research, Inc., [Alptekin et al. 2016] ET-PSA unit packed with nitrogen-doped activated carbon (AC) worked at about $200{ }^{\circ} \mathrm{C}$. The TDA's pre-combustion $\mathrm{CO}_{2}$ capture system achieves a net plant efficiency of $34 \%$ on a coal high heating value (HHV) basis. This net plant efficiency is higher than that can be achieved for the Selexol scrubber (31.6\%). Zhu et al. [Zhu et al. 2016] evaluated the $\mathrm{CO}_{2}$ capture energy consumption in IGCC power plant. The energy efficiency was highly related to the syngas recovery. With the optimization of ET-PSA process, the energy efficiency with ET-PSA was significantly higher than that with Selexol.

It should be noted that the performance of ET-PSA in IGFC has rarely been analyzed before. In this study, the energy consumptions of Selexol and ET-PSA are quantitatively evaluated in an IGFC model. The Selexol process is a representative of traditional normal temperature purification methods. The model of ET-PSA unit with a 4-2-1 process (4 adsorption towers, 2 pressure equalizations and 1 adsorption per cycle) was developed using the gPROMs commercial software. Tail gas reflux and high-pressure steam rinse were added to the ET-PSA process. The $\mathrm{CO}_{2}$ capture and syngas purification energy consumption was evaluated by the power efficiency penalty due to $\mathrm{CO}_{2}$ removal and the amount of $\mathrm{CO}_{2}$ captured.

\section{Methodology}

\subsection{Models}

\subsubsection{IGFC system model}

The foundation of the 500 MW IGFC power plant model built in this study originated 
from the National Energy Technology Laboratory (NETL) reports [Newby et al. 2011; Field et al. 2011; Liu 2014], which concluded the cost and performance of IGCC and IGFC projects supported by DOE. The IGFC power plant contained 6 subsystems: the GE-Texaco gasification subsystem (GASIFIER), the air separation subsystem (ASU), the water gas shift subsystem (WGS), the syngas purification and $\mathrm{CO}_{2}$ capture subsystem (Selexol or PSA), the SOFC subsystem and the steam turbine subsystem (ST). The sketch of IGFC with Selexol and ET-PSA is exhibited in Fig.1.

\section{Fig.1. Sketch of IGFC system with (a) Selexol and (b) ET-PSA.}

In GASIFIER subsystem, Illinois NO.6 coal was selected as the fuel. It reacted with pure oxygen produced by cryogenic method in ASU, which contained a four-stage intercooler compression. The working condition of the gasifier was $5.6 \mathrm{MPa}$ and $1300-1400^{\circ} \mathrm{C}$. High temperature syngas produced in this step cooled down to $200-300^{\circ} \mathrm{C}$ in a heat recovery boiler. After going through the necessary purification process, such as filter and organic matter removal, the syngas entered WGS subsystem, where sour shift occurred and $\mathrm{CO}$ was converted into $\mathrm{CO}_{2}$. The initial steam-syngas ratio was $2: 1$, the temperature being around $400^{\circ} \mathrm{C}$. The $\mathrm{CO}_{2}$ and $\mathrm{H}_{2} \mathrm{~S}$ in shift gas were removed in Selexol or ET-PSA unit. Purified syngas was then consumed in SOFC unit. Herein, a few assumptions proposed in publications [Field et al. 2011; Spallina et al 2011; Fernandes et al. 2015] were adopted, hence the fuel cell was represented by a combustor module. The power generation efficiency of the fuel cell was set as $55 \%$. Because the $\mathrm{H}_{2}, \mathrm{CO}, \mathrm{CH}_{4}$ and other fuels could not be totally converted in the fuel cell, the tail gas of fuel sell was ignited in a combustion chamber. 
The heat generated was used to preheat and reheat the steam in ST. Then in ST subsystem, the mechanical energy of steam was exploit by three steam turbines: high pressure turbine (HP), intermediate pressure turbine (IP) and low pressure one (LP). The rinse steam in ET-PSA came from the exhaust gas of HP while the purge steam was the exhaust gas of LP. In order to adequately take advantage of the thermal energy of steam, a steam reheat step was added between HP and IP.

In Selexol unit, the $\mathrm{H}_{2} \mathrm{~S}$ was removed in the desulfurizing tower by lean Selexol solution while $\mathrm{CO}_{2}$ was removed in decarbonizing tower by processed Selexol solution. The temperature and pressure for desulfurizing and decarbonizing were kept at $34^{\circ} \mathrm{C}, 5.1 \mathrm{MPa}$. The $\mathrm{H}_{2} \mathrm{~S}$-rich Selexol solution was heated in the heat exchanger before being regenerated via heating in the desorption tower at $0.1 \mathrm{MPa}$. The bottom temperature of desorption tower was kept at $160^{\circ} \mathrm{C}$, and the overhead temperature was $48^{\circ} \mathrm{C}$. The syngas rich in $\mathrm{H}_{2} \mathrm{~S}$ was obtained during regeneration process. The solution was then cooled, compressed, and absorbed $\mathrm{CO}_{2}$ in the decarbonizing tower. The $\mathrm{CO}_{2}$-rich Selexol solution was regenerated via pressure drop, and the regenerated pressure in the flash tank was also set at $0.1 \mathrm{MPa}$. The removed $\mathrm{CO}_{2}$ in Selexol subsystem was compressed to $15.27 \mathrm{MPa}$ in the $\mathrm{CO}_{2}$ compression subsystem to form high pressure liquid for transportation and storage.

The ET-PSA subsystem was represented by a separator module whose parameters such as product purity, recovery rate and steam consumption amount were decided by the outcomes of another model in gRPOMS.

\subsubsection{ET-PSA subsystem model}


A four-bed ET-PSA model was built in a commercial software gPROMS. Calgon 207C activated carbon (AC) impregnated by hydroxyl silicone oil was adopted as the adsorbent. After surface treatment, the adsorbent became hydrophobic and it could be used in ET-PSA with steam rinsing and purging [Hao et al. 2020]. The $\mathrm{CO}_{2}$ adsorption isotherm and kinetic behavior of AC was tested and described by Langmuir model and linear driven force model. The experiment data and fitting results are shown in Fig. 2. The relative adsorption/desorption rate of $\mathrm{H}_{2}$ and $\mathrm{CO}_{2}$ was similar hence the corresponding parameters were set as the same.

Fig. 2. (a) $\mathrm{CO}_{2}$ and $\mathrm{H}_{2}$ adsorption isotherms and Langmuir fit (b) $\mathrm{CO}_{2}$ adsorption/desorption kinetics performance and LDF fit.

In order to simplify the problem and the model, a few assumptions were proposed:

1. The temperature is uniform and fixed at the operating temperature $\left(170^{\circ} \mathrm{C}\right)$.

2. The adsorption beds whose height-diameter ratio is 20:1 could be regarded as one-dimensional.

3. $\mathrm{CO}_{2}, \mathrm{H}_{2}$, low pressure steam and other gases could be treated as ideal gases at the operating temperature.

The pressure distribution was captured by Ergun's equation

$-\sum \frac{\partial P_{i}}{\partial z}=150 \mu v \frac{\left(1-e_{b}\right)^{2}}{d_{p}^{2} e_{b}^{3}}+1.75 \frac{\sum \rho_{i}}{d_{p}} \frac{1-e_{b}}{e_{b}^{3}} v|v|$

The mass balance of gases could be described by the following equation:

$\frac{\partial C_{i}}{\partial \mathrm{t}}=\left(\sum C_{i}\right) D \frac{\partial^{2} X_{i}}{\partial z^{2}}+D \frac{\partial\left(\sum C_{i}\right)}{\partial z} \frac{\partial X_{i}}{\partial z}-\frac{\partial\left(v C_{i}\right)}{\partial z}-\rho_{p} \frac{1-e_{b}}{e_{b}} \frac{\partial q_{i}}{\partial t}$

Considering the amount of $\mathrm{CH}_{4}, \mathrm{CO}$ and some other impurities in syngas was much lower than $\mathrm{H}_{2}$ and $\mathrm{CO}_{2}$. The adsorption capacity of $\mathrm{CH}_{4}$ and $\mathrm{CO}$ was also close to 
$\mathrm{CO}_{2}$ and much higher than $\mathrm{H}_{2}$. They were thus regarded as $\mathrm{CO}_{2}$ in simulation and the diffusion coefficient was calculated by the formula:

$D\left(\sum P_{i}\right)\left(1 / M_{H_{2}}+1 / M_{C O_{2}}\right)^{-0.5}\left(V_{D-H_{2}}^{1 / 3}+V_{D-C O_{2}}^{1 / 3}\right)^{2}=0.04357 T^{1.5}$

This ET-PSA model has been validated and reported in our previous work [Hao et al.

2018]. Herein, a 4-2-1 process with rinse and purge gas reflux was adopted. The details are exhibited in Table 1 and Fig. 3. Each cycle contains 10 steps: adsorption (AD), steam rinse (R), pressure equalization drop (ED1, ED2), blow down (BD), purge $(\mathrm{Pu})$, pressure equalization rise (ER1, ER2), idle (I) and pressurization (PP). In order to improve the product gas recovery rate, gas reflux was added into the unit, which means a part of the tail gas during blow down and purge process was pressurized and flow into the adsorption bed again. It would recover some effective gas from tail gas, but surely increase the burden of adsorption process and bring in some electric energy consumption. Here the gas reflux ratio was 50\%. The steam consumption amount at rinse and purge step was both $8.3 \mathrm{~mol} \%$ of the feed gas. The length of one cycle was 1080s.

Table 1. Four bed, two pressure equalization, one adsorption (4-2-1) process with rinse and tail gas reflux.

Fig. 3. 4-2-1 PSA process with steam rinse and tail gas reflux.

\subsection{Analytical methods}

In Selexol, the major energy consumption originated from the heating process during absorbent regeneration. In ET-PSA, adsorbents could adsorb and desorb with the variation of $\mathrm{CO}_{2}$ partial pressure and heating could thus be avoided. However, the 
consumption of high temperature steam in ET-PSA would lead to the decreasing of electric production amount in ST subsystem. The $\mathrm{H}_{2}$ recovery rate and electric energy consumption of ET-PSA and Selexol was both different. It would be difficult to directly compare the efficiency of ET-PSA and Selexol. Hence, specific primary energy consumption for $\mathrm{CO}_{2}$ avoided (SPECCA) [Gazzani et al. 2013] was adopted as the parameter to represent capture energy consumption. The definition is as follows:

SPECCA $=\frac{3600\left(\frac{1}{\eta}-\frac{1}{\eta_{\text {none }}}\right)}{E_{\text {none }}-E}(\mathrm{~kJ} / \mathrm{kg})$

Where $E$ is the $\mathrm{CO}_{2}$ emission rate $(\mathrm{kg} / \mathrm{kWh}) ; \eta$ represents the net electrical efficiency and none represents the IGFC system in which $\mathrm{H}_{2} \mathrm{~S}$, and $90 \% \mathrm{H}_{2} \mathrm{O}$ is removed from the syngas before SOFC subsystem and there is no energy consumption during syngas purification. The definition of $\eta$ is:

$\eta=\frac{\text { Net Power (MW) }}{\text { Thermal power input,high heating value (MW) }}$

The SPECCA is a function of the amount of $\mathrm{CO}_{2}$ capture ratio (CCR) and $\mathrm{H}_{2}$ recovery ratio (HRR), which are defined as follows:

$\mathrm{CCR}=\frac{\text { inlet } \mathrm{CO}_{2} \text { amount }(\mathrm{mol})-\text { outlet } \mathrm{CO}_{2} \text { amount }(\mathrm{mol})}{\operatorname{inlet} \mathrm{CO}_{2} \operatorname{amount}(\mathrm{mol})}$

$\mathrm{HRR}=\frac{\text { outlet } \mathrm{H}_{2} \text { amount }(\mathrm{mol})}{\text { inlet } \mathrm{H}_{2} \text { amount }(\mathrm{mol})}$

In fact, with the rising of CCR, the HRR will deteriorates and SPECCA will increase. Therefore, the CCR of these two systems should be set to the same value to exclude irrelevant variables. Specifically, it could be realized by regulating the flow rate of absorbent in Selexol and the cycle duration of ET-PSA.

\section{Results and discussion}




\subsection{Stream balance of the streams in IGFC}

The conditions of the streams in IGFC with Selexol and ET-PSA are listed in Tables 2 and 3 respectively. ASU and GASIFIER were in the upstream section of IGFC and they were almost not influenced by gas separation subsystem. Hence the conditions of corresponding streams like "SYNGAS1", "ASHWATER" were nearly same in system one and system two. Before purification, the syngas was mainly composed of $\mathrm{CO}_{2}$, $\mathrm{H}_{2} \mathrm{O}$ and $\mathrm{H}_{2}$. Most $\mathrm{H}_{2} \mathrm{O}$ was removed by heat transfer and gas-liquid separation. During purification process in Selexol unit, the syngas temperature decreased from $236^{\circ} \mathrm{C}$ to $36^{\circ} \mathrm{C}$. A part of sensible heat of syngas was lost in this step. In system two, the syngas was purified at elevated temperatures and some steam remained in the syngas and enters into the SOFC subsystem with $\mathrm{H}_{2}$. Compared with that in system one, the syngas coming from ET-PSA was at higher temperature, more heat energy being infused into SOFC and ST subsystems and the steam flow rate in turbines became larger. Because of the consumption of steam during rinse and purge, the flow rate of "HOTSTREAM", "HSTR" and "STREAM" was different.

Table 2. Stream balance of the streams in system one.

Table 3. Stream balance of the streams in system two.

\subsection{Syngas purification and $\mathrm{CO}_{2}$ capture energy consumption}

CCR and HHR could be calculated from the data listed in Tables 2 and 3. In system one, it was $90.4 \%$ and $99.3 \%$ respectively, while the corresponding outcomes in system two was $90.8 \%$ and $98.8 \%$. The purification efficiency was similar and the energy consumption was thus comparable. 
Syngas purification and $\mathrm{CO}_{2}$ capture energy consumption could be represented by SPECCA. The outcomes of system one and two are listed in Table 4. The power generation mainly contained three parts: SOFC power, steam turbines power and the power generated during purified gas expanding. The amount of SOFC power depended on the syngas flow rate and fuel cell efficiency. Herein, the latter was set as $55 \%$, and $80 \%$ of the fuel reacted in the SOFC. The chemical energy of the remained fuel was converted into thermal energy in the tail gas combustor. Steam turbines power was closely related to the thermal energy in IGFC system. When more energy was supplied to ST, the steam flow rate in this subsystem could be larger. Less sensible heat being wasted during purification process, the total power generation amount in system two was higher than system one.

Table 4. Gas purification and $\mathrm{CO}_{2}$ removal energy consumption $\left(90 \% \mathrm{CO}_{2}\right.$ capture rate).

The auxiliary load included transferring device load and the energy consumption of compressors and pumps in ASU, ET-PSA, Selexol and ST subsystems. In ASU, air, oxygen or nitrogen needed to be compressed to high pressure, plus the flow rate of these gases was large, similar to the flow rate of syngas produced in gasification. Hence the energy consumption in this subsystem was much larger than others. Then in ET-PSA subsystem, when the reflux ratio rose, both the HRR and the energy consumption of the tail gas compressor would increase. However, because the power required by the compressor in ET-PSA was much less than Selexol, the improvement of HRR could overwhelm this part of energy consumption increase. After 
pre-optimization, we found the reflux ratio of $50 \%$ was a preferred setting. In Selexol subsystem, the pressure of the $\mathrm{CO}_{2}$ obtained in Selexol was higher than ET-PSA, thus the energy consumption of $\mathrm{CO}_{2}$ compressor was less.

Taking both power generation and consumption amounts into account, the net power efficiency in system one and two was respectively $30.9 \%$ and $34.1 \%$ while the emission of $\mathrm{CO}_{2}$ was similar. The corresponding SPECCA was 3.46 and $1.80(\mathrm{~kJ} / \mathrm{KG})$. The $\mathrm{CO}_{2}$ capture energy consumption using ET-PSA was 52\% of that using Selexol.

IGFC is only one of the situations in which syngas purification is needed. In actual production, the $\mathrm{H}_{2}$ produced by coal gasification is usually used for synthesizing ammonia, methanol and petroleum refining, where the requirement for $\mathrm{H}_{2}$ purity will be much stricter and the CCR is also much higher. The energy consumption of deep $\mathrm{CO}_{2}$ removal is worth analyzing and another case was thus performed, in which the $\mathrm{CO}_{2}$ capture rate was $99 \%$. The corresponding simulation results are listed in Table 5.

Table 5. Gas purification and $\mathrm{CO}_{2}$ removal energy consumption $\left(99 \% \mathrm{CO}_{2}\right.$ capture rate).

Since the amount of $\mathrm{CO}_{2}$ captured became larger and the purity of product gas got improved, inevitably the HRR dropped, which led to the decreasing of total power generation amount. In Selexol and ET-PSA, the HRR was $97.8 \%$ and $94.5 \%$ respectively. The corresponding power generation amount decreased by $1.2 \%$ and 4.9\%. Compared with the results in Table 4, the variation of auxiliary load was not obvious. The rise of "acid and $\mathrm{CO}_{2}$ removal" in Selexol originated from the extra pump work resulting from the increasing solvent amount. In total, SPECCA witnessed 
a great rise when $\mathrm{CO}_{2}$ capture rate varies from $90 \%$ to $99 \%$. For Selexol, it varied from 3.46 to $3.66 \mathrm{~kJ} / \mathrm{kg}$, while the variation was much larger for ET-PSA. The SPECCA of ET-PSA increased by 50\%. Although the growth rate of ET-PSA was much larger than Selexol, the gas separation energy consumption (SPECCA) of the former one was still only $74 \%$ of the later technology.

\section{Conclusion}

In this study, the $\mathrm{CO}_{2}$ capture energy consumption of ET-PSA and Selexol in IGFC power plant was analyzed. IGFC models with and without $\mathrm{CO}_{2}$ capture were built in Aspen Plus, in which the efficiency penalty caused by pre-combustion $\mathrm{CO}_{2}$ capture was analyzed. Four bed-two equalization-one adsorption ET-PSA process with steam rinse and tail gas reflux was simulated in gPROMS. Compared to the Selexol process, ET-PSA was able to recover the sensible heat of syngas, bringing about more power generation in steam turbines. When the $\mathrm{CO}_{2}$ capture rate was $90 \%$ and $99 \%$, SPECCA of ET-PSA was 1.80 and $2.72 \mathrm{~kJ} / \mathrm{kg}$, respectively, while the data for Selexol was 3.46 and $3.66 \mathrm{~kJ} / \mathrm{kg}$, respectively. ET-PSA was demonstrated to be superior on the aspect of energy efficiency and had the potential to be applied in IGFC power plant and other situations for $\mathrm{CO}_{2}$ capture and syngas purification.

\section{Nomenclature}

$t=$ time, $\mathrm{s}$

$M_{i}=$ molecular mass of $i, i=\mathrm{H}_{2}, \mathrm{CO}_{2}, \mathrm{~g} \cdot \mathrm{mol}^{-1}$ 
$R=$ ideal constant $\mathrm{J} \cdot \mathrm{mol}^{-1} \cdot \mathrm{K}^{-1}$

$T$ = temperature in adsorption bed, $\mathrm{K}$

$P_{i}=$ partial pressure of $i, i=\mathrm{H}_{2}, \mathrm{CO}_{2}, \mathrm{~Pa}$

$C_{i}=$ molar concentration of $i, i=\mathrm{H}_{2}, \mathrm{CO}_{2}, \mathrm{~mol} \cdot \mathrm{m}^{-3}$

$X_{i}=$ mole fraction of $i, i=\mathrm{H}_{2}, \mathrm{CO}_{2}$,-

$\rho_{i}=$ density of $i, i=\mathrm{H}_{2}, \mathrm{CO}_{2}, \mathrm{~kg} \cdot \mathrm{m}^{-3}$

$\rho_{p}=$ adsorbent density, $\mathrm{kg} \cdot \mathrm{m}^{-3}$

$k=$ parameter related to $\mathrm{H}_{2}$ adsorption capacity, $\mathrm{mmol} \cdot \mathrm{g}^{-1} \cdot \mathrm{Mpa}^{-1}$

$e_{b}=$ void fraction of adsorption bed, $\mathrm{MPa}^{-1}$

$d_{p}=$ adsorbent diameter in adsorption bed, $\mathrm{m}$

$q_{i}=$ adsorption quantity of $i, i=\mathrm{H}_{2}, \mathrm{CO}_{2}, \mathrm{mmol} \cdot \mathrm{g}^{-1}$

$z=$ height in bed, $\mathrm{m}$

$v=$ flow speed in bed, $\mathrm{m} \cdot \mathrm{s}^{-1}$

$\mu=$ gas dynamic viscosity, $\mathrm{Pa} \cdot \mathrm{s}$

$D=$ diffusion coefficient $\mathrm{m}^{2} \cdot \mathrm{s}^{-1}$

$V_{D-i}=$ liquid state molar volume of $i, i=\mathrm{H}_{2}, \mathrm{CO}_{2}, \mathrm{~cm}^{3} / \mathrm{gmol}$

$R_{\text {bed }}=$ adsorption bed radius, $\mathrm{m}$

$q_{e-i}=$ adsorption capacity of $i$ at given pressure, $i=\mathrm{H}_{2}, \mathrm{CO}_{2}, \mathrm{mmol} \cdot \mathrm{g}^{-1}$

$q_{s-i}=$ saturated adsorption capacity of $i, i=\mathrm{H}_{2}, \mathrm{CO}_{2}, \mathrm{mmol} \cdot \mathrm{g}^{-1}$

$b_{i}=$ Langmuir model adsorption parameter, $i=\mathrm{H}_{2}, \mathrm{CO}_{2}, \mathrm{MPa}^{-1}$

$F_{\text {in }}=$ inlet flow rate, $\mathrm{Nm}^{3} \cdot \mathrm{h}^{-1}$

$F_{\text {out }}=$ outlet flow rate, $\mathrm{Nm}^{3} \cdot \mathrm{h}^{-1}$ 
$F_{\text {feed }}=$ feed gas flow rate, $\mathrm{Nm}^{3} \cdot \mathrm{h}^{-1}$

$P_{\text {feed }}=$ feed pressure, $\mathrm{Pa}$

$P_{\text {blowdown }}=$ blowdown pressure, $\mathrm{Pa}$

$v_{i n}=$ inlet flow velocity, $\mathrm{m} \cdot \mathrm{s}^{-1}$

$v_{\text {out }}=$ outlet flow velocity, $\mathrm{m} \cdot \mathrm{s}^{-1}$

$L=$ bed height, $\mathrm{m}$

$k_{a-i}=\mathrm{LDF}$ parameter of adsorption, $i=\mathrm{H}_{2}, \mathrm{CO}_{2}, \mathrm{~s}^{-1}$

$k_{d-i}=\mathrm{LDF}$ parameter of adsorption, $i=\mathrm{H}_{2}, \mathrm{CO}_{2}, \mathrm{~s}^{-1}$

$F_{a d s}=$ outlet flow rate of the bed which is at adsorption step, $\mathrm{Nm}^{3} \cdot \mathrm{h}^{-1}$

$F_{L P}=$ outlet flow rate of the bed which is at final pressurization step, $\mathrm{Nm}^{3} \cdot \mathrm{h}^{-1}$

$F_{P u}=$ outlet flow rate of the bed which is at purge step, $\mathrm{Nm}^{3} \cdot \mathrm{h}^{-1}$

$F_{E D 1}, F_{E D 2}=$ outlet flow rate of the bed which is at pressure equalization drop step,

$\mathrm{Nm}^{3} \cdot \mathrm{h}^{-1}$

$F_{E R 1}, F_{E R 2}=$ inlet flow rate of the bed which is at pressure equalization rise step,

$\mathrm{Nm}^{3} \cdot \mathrm{h}^{-1}$

$C_{V 1}, C_{V 2}=$ valve parameter in pressure equalization step, $\mathrm{Nm}^{3} \cdot \mathrm{Pa}^{-1} \cdot \mathrm{h}^{-1}$

$x_{\text {feed }-i}=$ molar fraction of $i$ in feed gas, $i=\mathrm{H}_{2}, \mathrm{CO}_{2}$,-

$x_{\text {ads }-i}=$ molar fraction of $i$ in production, $i=\mathrm{H}_{2}, \mathrm{CO}_{2},-$

\section{Declarations}

Funding: This research was financed by National Key R\&D Program of China (2017YFB0601900). 
Conflicts of interest/Competing interests: The authors declare no competing interests. Availability of data and material: Not applicable.

Code availability: Not applicable.

Authors contribution: Yixiang Shi and Ningsheng Cai conceived the project. Peixuan Hao, Xuancan Zhu and Shuang Li built the models. Peixuan Hao performed the analysis.

Acknowledgment: Not applicable.

\section{References}

Alptekin G, Jayaraman A, Dietz S, 2016. Low Cost, High Capacity Regenerable Sorbent for Carbon Dioxide Capture from Existing Coal-fired Power Plants. TDA Research, Inc., Wheat Ridge, CO (United States).

Ameri M, Mohammadi R, 2013. Simulation of an atmospheric SOFC and gas turbine hybrid system using Aspen Plus software. International journal of energy research, 37: 412-425.

Coenen K, Gallucci F, Pio G, Cobden P, van Dijk, E, Hensen E, van Sint Annaland M, 2017. On the influence of steam on the $\mathrm{CO} 2$ chemisorption capacity of a hydrotalcite-based adsorbent for SEWGS applications. Chemical Engineering Journal, 314: 554-569.

Fernandes A, Woudstra T, Aravind P V, 2015. System simulation and exergy analysis on the use of biomass-derived liquid-hydrogen for SOFC/GT powered aircraft. International Journal of Hydrogen Energy, 40: 4683-4697 
Field R P, Brasington R, 2011. Baseline flowsheet model for IGCC with carbon capture. Industrial \& Engineering Chemistry Research, 50: 11306-11312.

Gazzani M, Macchi E, Manzolini G, 2013. CO2 capture in integrated gasification combined cycle with SEWGS - Part A: thermodynamic performances. Fuel, 105: 206-19.

Hajabdollahi Z, Fu P F, 2017. Multi-objective based configuration optimization of SOFC-GT cogeneration plant. Applied Thermal Engineering, 112: 549-559.

Hao P, Shi Y, Li S, Cai N, 2020. Hydrophobic activated carbon for elevated-temperature pressure swing adsorption. Adsorption, 1-8.

Hao P, Shi Y, Li S, Zhu X, Cai N, 2018. Correlations between adsorbent characteristics and the performance of pressure swing adsorption separation process. Fuel, 230: 9-17.

Lanzini A, Kreutz T G, Martelli E, Santarelli M, 2014. Energy and economic performance of novel integrated gasifier fuel cell (IGFC) cycles with carbon capture. International journal of greenhouse gas control, 26: 169-184.

Li S, Shi Y, Yang Y, Zheng Y, Cai N, 2013. High-performance CO2 adsorbent from interlayer potassium-promoted stearate-pillared hydrotalcite precursors. Energy \& fuels, 27: 5352-5358.

Liu Z, 2014. Investigation of adsorbent-based warm carbon dioxide capture technology for IGCC system (Doctoral dissertation, Massachusetts Institute of Technology). 
Mehrpooya M, Akbarpour S, Vatani A, Rosen M, A, 2014. Modeling and optimum design of hybrid solid oxide fuel cell-gas turbine power plants. International journal of hydrogen energy, 39: 21196-21214.

Mohammed I Y, Samah M, Mohamed A, Sabina G, 2014. Comparison of SelexolTM and Rectisol® technologies in an integrated gasification combined cycle (IGCC) plant for clean energy production. International Journal of engineering research, 3: $742-744$.

Newby R, Keairns D, 2011. Analysis of Integrated Gasification Fuel Cell Plant Configurations. No. NETL/DOE-2011/1482. NETL.

Qiao Y, Wang J, Zhang Y, Gao W, Harada T, Huang L, Hatton T A, Wang Q, 2017. Alkali nitrates molten salt modified commercial $\mathrm{MgO}$ for intermediate-temperature $\mathrm{CO} 2$ capture: optimization of the $\mathrm{Li} / \mathrm{Na} / \mathrm{K}$ ratio. Industrial \& Engineering Chemistry Research, 56: 1509-1517.

Reynolds S P, Ebner A D, Ritter J A, 2006. Stripping PSA cycles for CO2 recovery from flue gas at high temperature using a hydrotalcite-like adsorbent. Industrial \& engineering chemistry research, 45: 4278-4294.

Sarmah P, Gogoi T K, 2017. Performance comparison of SOFC integrated combined power systems with three different bottoming steam turbine cycles. Energy Conversion and Management, 132: 91-101.

Spallina V, Romano M C, Campanari S, Lozza G, 2011. A SOFC-based integrated gasification fuel cell cycle with $\mathrm{CO} 2$ capture. Journal of engineering for gas turbines and power, 133. 
Zhang R, Zhang X, Yang Q, Yu H, Liang Z, Luo X, 2017. Analysis of the reduction of energy cost by using MEA-MDEA-PZ solvent for post-combustion carbon dioxide capture (PCC). Applied Energy, 205: 1002-1011.

Zhu X, Shi Y, Cai N, 2016. Integrated gasification combined cycle with carbon dioxide capture by elevated temperature pressure swing adsorption. Applied Energy, 176: 196-208.

Zhu X, Shi Y, Li S, Cai N, 2018. Two-train elevated-temperature pressure swing adsorption for high-purity hydrogen production. Applied Energy, 229: 1061-1071. 
Figures
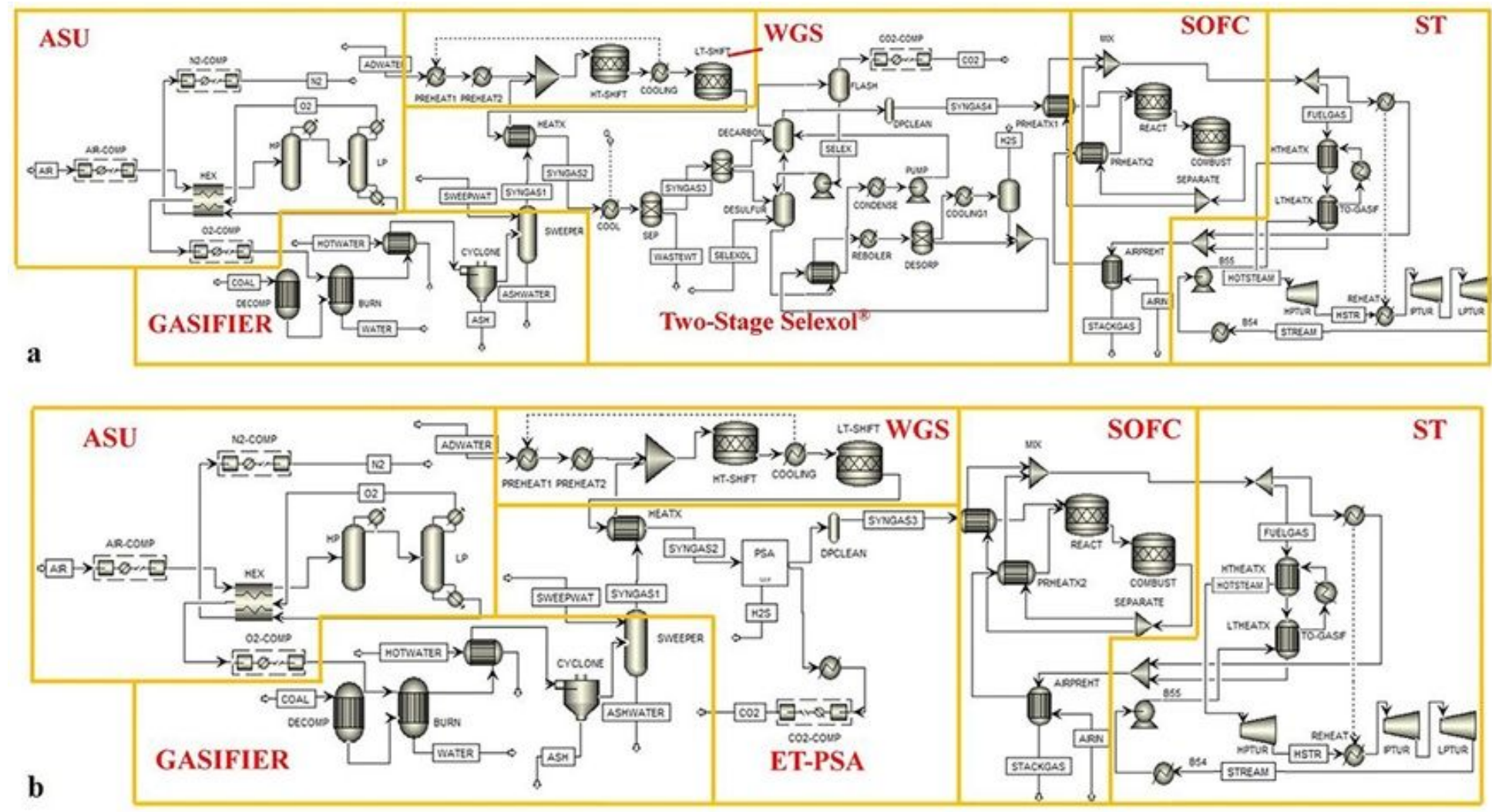

Figure 1

Sketch of IGFC system with (a) Selexol (named system 1) and (b) ET-PSA (system 2). 

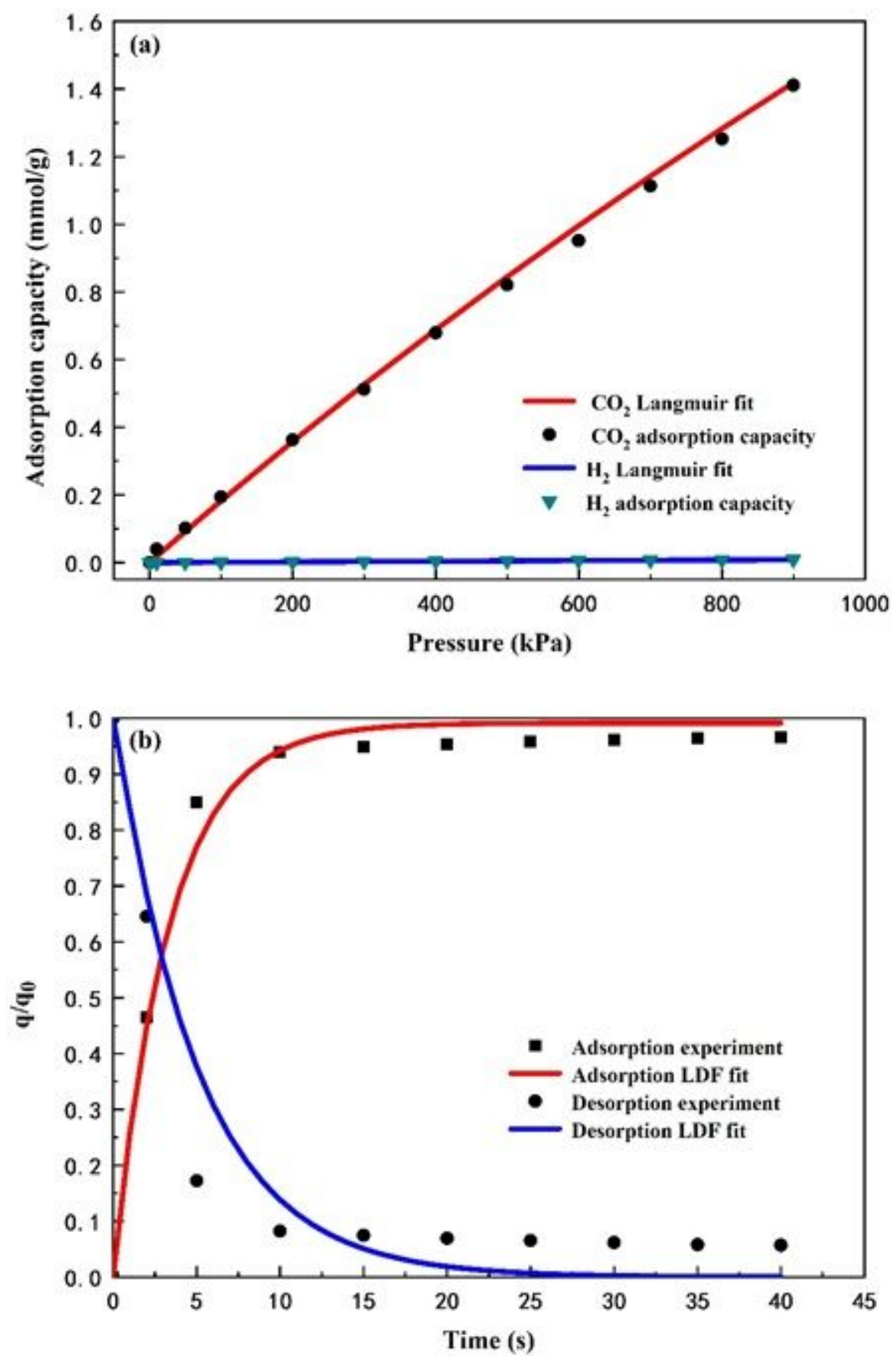

Figure 2

(a) $\mathrm{CO} 2$ and $\mathrm{H} 2$ adsorption isotherms and Langmuir fit (b) $\mathrm{CO} 2$ adsorption/desorption kinetics performance and LDF fit. 


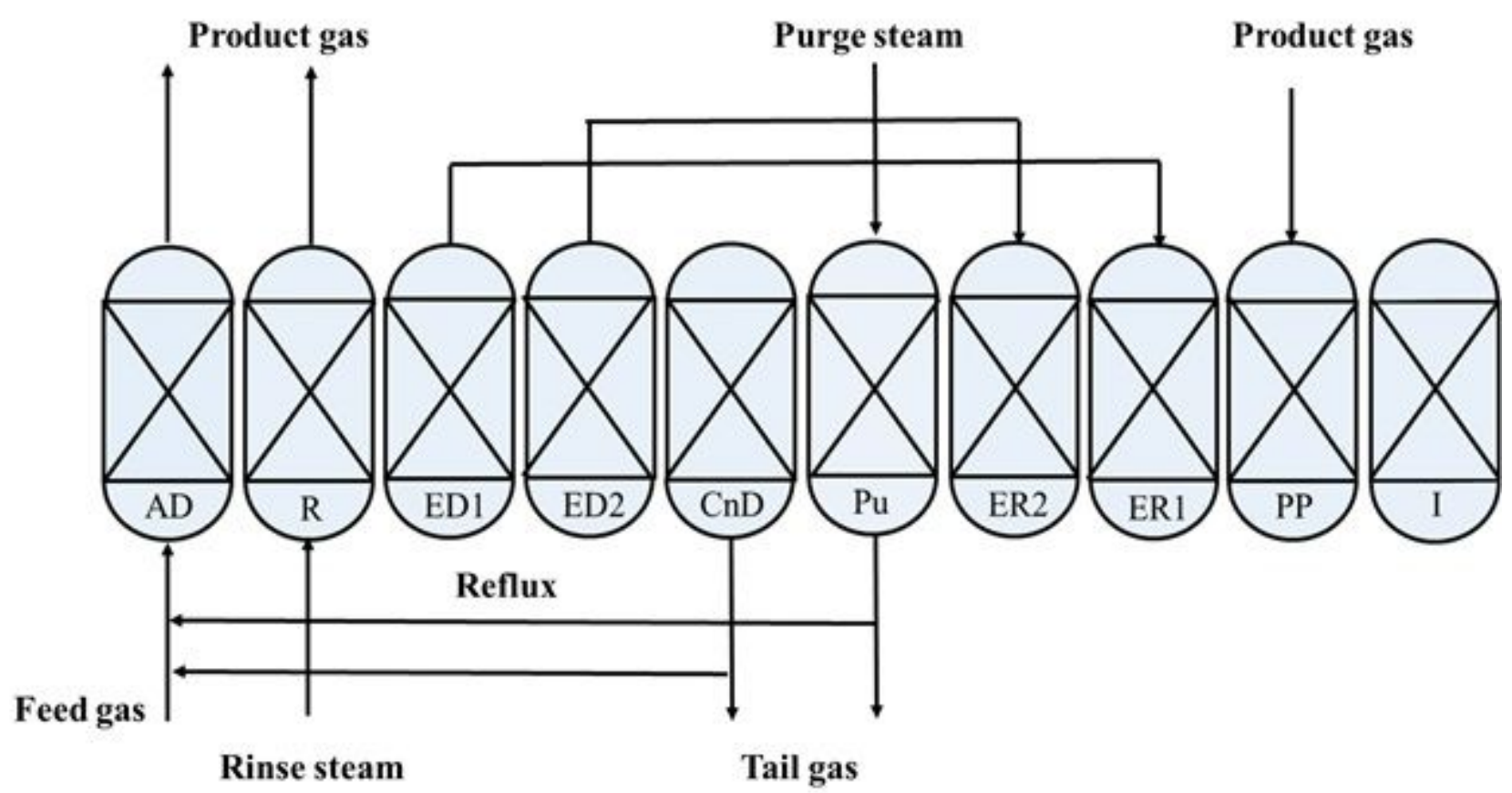

Figure 3

4-2-1 PSA process with steam rinse and tail gas reflux.

\section{Supplementary Files}

This is a list of supplementary files associated with this preprint. Click to download.

- figures.rar 